\title{
First confirmed record of Jaguarundi, Herpailurus yagouaroundi (É. Geoffroy, 1803) (Mammalia, Carnivora, Felidae), on the western slope of the Peruvian Andes
}

\author{
Alvaro García-Olaechea ${ }^{1,2}$, Robyn D. Appleton ${ }^{1,3}$, Renzo P. Piana $^{1}$ \\ 1 Spectacled Bear Conservation Society, La Quinta S/N, Batán Grande, Lambayeque, Perú. 2 Centro de Investigación Biodiversidad Sostenible \\ - BioS. Calle Francisco de Zela 1556, Lince, Lima 14, Perú. 3 Department of Forest and Conservation Sciences, University of British Columbia, \\ 3041-2424 Main Mall, Vancouver, British Columbia, V6T 1Z4, Canada. \\ Corresponding author: Alvaro García-Olaechea, agarolae@yahoo.com
}

\begin{abstract}
The presence of the Jaguarundi, Herpailurus yagouaroundi, west of the Peruvian Andes have not been considered in recent studies due to lack of evidence. We document its presence in the Laquipampa Wildlife Refuge, on the western slope of the Peruvian Andes, using camera traps. The closest previous record was approximately $129 \mathrm{~km}$ north, in a montane forest of Amazonas region on the eastern slope of the Andes. It is imperative that further research is conducted on carnivore species west of the Peruvian Andes to better understand the distribution of lesser known species such as the Jaguarundi.
\end{abstract}

\section{Keywords}

Camera trapping, carnivore, Laquipampa Wildlife Refuge, montane forest, new record.

Academic editor: Guilherme S. T. Garbino | Received 22 May 2019 | Accepted 6 September 2019 | Published 4 October 2019

Citation: García-Olaechea A, Appleton RD, Piana RP (2019) First confirmed record of Jaguarundi, Herpailurus yagouaroundi (É. Geoffroy, 1803) (Mammalia, Carnivora, Felidae), in the western slope of the Peruvian Andes. Check List 15 (5): 875-878. https://doi.org/10.15560/15.5.875

\section{Introduction}

The Jaguarundi, Herpailurus yagouaroundi (É. Geoffroy, 1803), is a small feline (3.5-7.5 kg) widely distributed from southern USA to northern Argentina (Nowell and Jackson 1996). This species occurs in several habitat types, such as montane and tropical forests, savannas, swamps, riparian areas, dry scrubs, and grasslands close to freshwater (Nowell and Jackson 1996; Oliveira 1998). It occurs in an altitudinal range varying from sea level to $2200 \mathrm{~m}$ (Oliveira 1998; Giordano 2016). It can also be found in secondary and disturbed habitats, such as agricultural fields and oil palm plantations (Pardo-Vargas and Payán-Garrido 2015; Giordano 2016). Both in global and Peruvian endangered species lists, the Jaguarundi is categorized as Least Concern (Caso 2015; MINAGRI 2014), mainly because its wide geographic distribution.

Camera trap studies conducted in montane and lowland rainforests in Central and South America recorded few captures of Jaguarundi (Tobler et al. 2008; Di Bitetti et al. 2010; Hodge and Arbogast 2016; Briceño et al. 2017; Zimbres et al. 2018). They found that Jaguarundi was among the species with fewer independent records among the carnivore community, suggesting that it occurs at low densities throughout its range (Giordano 2016).

Despite its wide distribution in the Neotropics, information about the ecology and distribution of Jaguarundi 
in Peru is limited and almost restricted to the east of the Peruvian Andes (Emmons and Feer 1997; Giordano 2016). There is only one historic record from 50 years ago on the western slopes (Grimwood 1969). However, even though this historic record has been published, it was not considered in two recent publications focused on Jaguarundi distribution modeling (Silva et al. 2016; Espinosa et al. 2018).

Due to this lack of information, several authors have recommended a distribution update in Peru and an assessment of the connectivity among its populations (Cossíos et al. 2012; Hurtado et al. 2016). Here we report the first recent records of Herpailurus yagouaroundi in the western slopes of the Peruvian Andes.

\section{Methods}

This research was conducted from September 2015 to February 2016 in the Laquipampa Wildlife Refuge (LWR) $\left(06^{\circ} 20^{\prime} \mathrm{S}, 079^{\circ} 29^{\prime} \mathrm{W} ; 8328.64 \mathrm{ha}\right)$, a protected area created to preserve dry and mountain forests west of the Peruvian Andes (Fig. 1). In LWR, two main ecoregions are present: the Tropical Dry Forest ecoregion in the lowlands (from 200 to $1400 \mathrm{~m}$ a.s.1.) and the Montane Forest ecoregion (from 1400 to $2600 \mathrm{~m}$ a.sl.) (CDC-UNALM, 2006). In the dry forest, the most common tree species are Loxopterygium huasango Spruce ex Engl. (Anacardiaceae), Bursera graveolens (Kunth) Triana \& Planch (Burseraceae), and Eriotheca ruizii (K. Schum.) A. Robyns (Malvaceae), while in the montane forest, there are Cedrela montana Moritz ex Turcz. (Meliaceae), Caesalpinia spinosa (Molina) Kuntze (Fabacea), Chusquea
(Kunth) (Poaceae), and shrubs, such as Barnadesia spp. (Asteraceae). Additionally, agricultural areas are found in the lowlands, near the Moyán and La Leche rivers (Angulo-Pratolongo et al. 2012).

We randomly defined 62 camera trap stations on a $1 \times$ $1 \mathrm{~km}$ grid from $426 \mathrm{~m}$ to $2610 \mathrm{~m}$ a.s.l. The cameras were installed during two periods: 31 stations were active from September to November, while the remaining 31 were moved to the other places within the grid from December to February (Fig. 1A). Each station included two camera traps (one Reconyx and one Bushnell Trophy Cam) facing each other at two sides of a game trail or waterholes. The cameras were set at approximately 40 $\mathrm{cm}$ above the ground, with no bait, and were set to take five photos (on Reconyx) and three photos (on Bushnell Trophy Cam) per trigger with a one second interval during 24 hours per day (Appleton et al. 2018).

We compared the Jaguarundi records within LWR with published literature and with three datasets that have records of this species (Silva et al. 2016; Hurtado et al. 2016; Espinosa et al. 2018).

\section{Results}

After 5641 camera/days and photographs of 1514 independent events ( $<60$ minutes) of medium-sized to large mammals, we obtained three records of the Jaguarundi. Two records were in the Montane Forest and one record was in the transition zone between the Tropical Dry Forest and the Montane Forest.

New records. a) Peru: Lambayeque Region, Ferreñafe

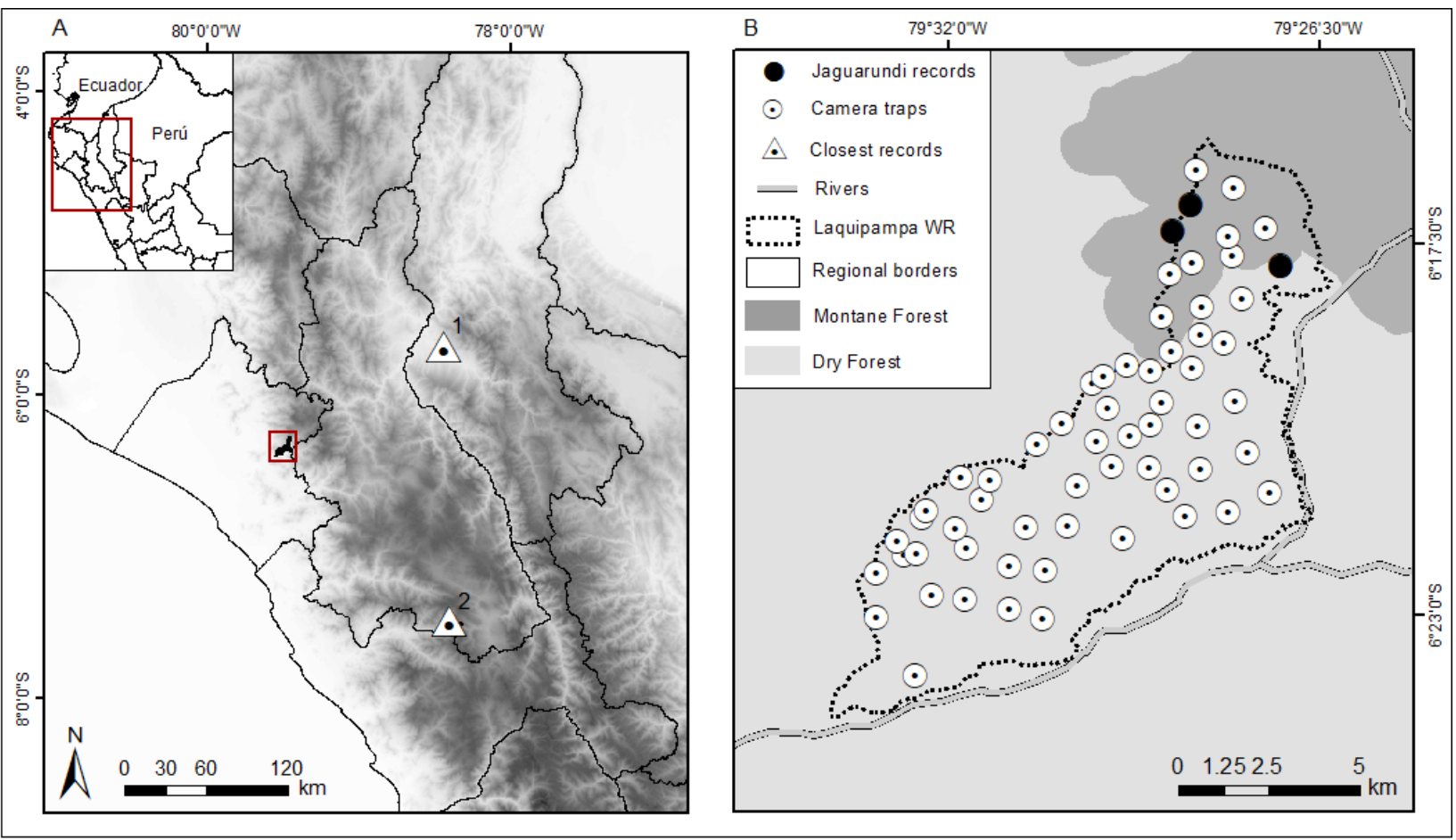

Figure 1. A. Laquipampa Wildlife Refuge and the two closest records of Jaguarundi. Record 1 is from Hurtado et al. (2016) and record 2 is from Grimwood (1969). B. Laquipampa Wildlife Refuge, showing the camera trap deployment and the sites where Jaguarundis were recorded. 


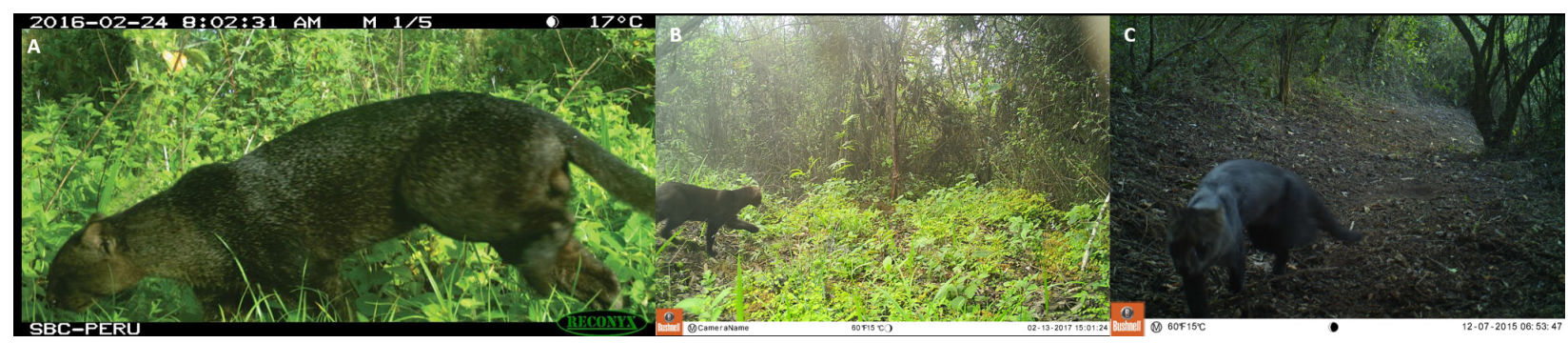

Figure 2. The three events of Jaguarundi Herpailurus yagouaroundi recorded in Laquipampa Wildlife Refuge, northwestern Peru

Province, Laquipampa Wildlife Refuge $\left(06^{\circ} 17.810^{\prime} \mathrm{S}\right.$, $079^{\circ} 27.067^{\prime} \mathrm{W}, 1379 \mathrm{~m}$ a.s.1.), 7 December 2015 at 06:54 h. b) Peru: Lambayeque Region, Ferreñafe Province, Laquipampa Wildlife Refuge $\left(06^{\circ} 17.306^{\prime} \mathrm{S}, 079^{\circ} 28.671^{\prime} \mathrm{W}\right.$, 2319 m a.s.1.), 13 February 2016 at 15:01 h. c) Peru: Lambayeque Region, Ferreñafe Province, Laquipampa Wildlife Refuge $\left(06^{\circ} 16.912^{\prime} \mathrm{S}, 079^{\circ} 28.398^{\prime} \mathrm{W}, 2400 \mathrm{~m}\right.$ a.s.1.), 24 February 2016 at 08:02 h (Fig. 2).

Identification. We identified the species as Herpailurus yagouaroundi because of its external characteristics, such as its relatively short limbs and elongated body with a proportionally small head and low and rounded ears (Oliveira 1998). Moreover, the individuals were dark brown without any coat markings (Fig. 2), and thus, were distinguishable from all other small Neotropical felids present in the LWR, i.e., the Ocelot Leopardus pardalis (Linnaeus, 1758) and the Pampas Cat Leopardus colocola (Molina, 1782). One of the photographed Jaguarundis was an adult male (Fig. 2A).

\section{Discussion}

Our records are the first recent evidence of the presence of Jaguarundi in the western slope of the Peruvian Andes. The two closest records to the ones we present here are approximately $129 \mathrm{~km}$ northeast in the Amazonas region $\left(05^{\circ} 40.667^{\prime} \mathrm{S}, 078^{\circ} 26.317^{\prime} \mathrm{W}\right)$, on the eastern slope of the Andes (Hurtado et al. 2016), and approximately $177 \mathrm{~km}$ southeast in the "Hacienda Sunchubamba" in the Cajamarca region, on the western slope of the Andes (Grimwood 1969) (Fig. 1A). Our records in the LWR highlight that Jaguarundi still persists in the western slope of the Peruvian Andes (Grimwood 1969), and corroborates Giordano's (2016) suspicion that Jaguarundi is present on this slope. This record also increases the known altitudinal range of this species in Peru by $200 \mathrm{~m}$.

Given the low number of Jaguarundi events obtained ( 3 of 1514; the species was recorded only at three camera stations out of the 62 deployed), we consider it rare in the LWR. In camera trap studies, a rare species is one with low habitat occupancy and low detection probability (Shannon et al. 2014). The rarity of Jaguarundi in the LWR is consistent with other studies (Tobler et al. 2008; Di Bitetti et al. 2010; Hodge and Arbogast 2016; Briceño et al. 2017; Zimbres et al. 2018) and could be attributed to its low density (Giordano 2016) or to the presence of other carnivores within the Wildlife Refuge, i.e., Ocelot,
Pampas Cat, Puma Puma concolor (Linnaeus, 1771), Andean Bear Tremarctos ornatus (Cuvier, 1825), Tayra Eira barbara (Linnaeus, 1758), Sechuran Fox Lycalopex sechurae (Thomas, 1900), and Striped Hog-nosed Skunk Conepatus semistriatus (Boddaert, 1785), which were more common than Jaguarundi and may compete with it (Linnell and Strand 2000; Giordano 2016). Furthermore, the "ocelot effect" could also explain the low events of Jaguarundi in the LWR. Given the medium to high number of records of Ocelots within our study area (25 events) and the overlap in diet and habitat preferences with Jaguarundi (Oliveira et al. 2010), it is possible that these species exclude each other, with Ocelots displacing Jaguarundis in the LWR, as has been shown in the Brazilian Amazon (Oliveira et al. 2010).

These records of Jaguarundi in the LWR were in the montane forest located at higher elevations on the east side of this protected area. Given that almost half of our camera traps were located in lower dry forest within LWR, it is possible that our survey design, aimed to cover as many ecosystems as possible, reduced the chances of detecting Jaguarundi in its preferred habitat. Although the species occurs in the dry forest of southwestern Ecuador (Espinosa et al. 2016), the lack of records for the region is evidenced in several camera trap surveys conducted in the dry forest of northwestern Peru (Hurtado and Pacheco 2015; García-Olaechea pers. comm.; Appleton pers. comm.). It is possible that more individuals occur northeast of the LWR where more montane forest is present. We recommend researchers to conduct camera trap surveys within these forests to better understand the distribution and habitat requirements of the jaguarundi and other carnivores west of the Peruvian Andes.

\section{Acknowledgements}

We thank to the authorities of Laquipampa Wildlife Refuge for the research authorization (No. 002-2015-SERNANP) and to the park rangers Napoleón Durán and Alejandro Gonzalez for they support setting the camera traps, as well to Javier Vallejos, José Vallejos, Isai Sánchez, Jonathan Vallejos, and Francis Aurich for their incredible fieldwork. We also thank Cindy Hurtado for her review of the first version of the manuscript and sharing her dataset, as well as Fabio Nascimento, Lucas Gonçalves, and an anonymous referee for their valuable comments. 


\section{Authors' Contributions}

AGO wrote the manuscript and made the map; RDA obtained the funds, implemented the study design and reviewed the final version of the manuscript; and RPP provided relevant comments and revisions through all the manuscript versions.

\section{References}

Angulo-Pratolongo F, Flanagan JNM, Vellinga W-P, Durand N (2012) Notes on the birds of Laquipampa Wildlife Refuge, Lambayeque, Peru. Bulletin of the British Ornithologists' Club 132: 162-174.

Appleton RD, Van Horn RC, Noyce KV., Spady TJ, Swaisgood RR, Arcese P (2018) Phenotypic plasticity in the timing of reproduction in Andean bears. Journal of Zoology 305: 196-202. https:// doi.org/10.1111/jzo.12553

Briceño M, Naranjo Piñera E, Pérez Irineo G, Sandoval Serés E, Contreras Perera Y, Hidalgo Mihart M (2017) Richness and trophic guilds of carnivorous mammals in ejido Nuevo Becal, Calakmul, Campeche, Mexico. Therya 8: 145-150. https://doi.org/10.12933/ therya-17-472

Caso A, de Oliveira T, Carvajal SV (2015) Herpailurus yagouaroundi. The IUCN Red List of Threatened Species 2015: e.T9948A50653167. https://doi.org/10.2305/iucn.uk.2015-2.rlts.t9 948a50653167.en. Accessed on: 2018-12-05.

Cossíos ED, Fajardo U, Alfaro-Shigueto J, Cárdenas-Alayza S, Valqui J, Montero FG, Lescano J, Quevedo M, Vivar E, Leite R, Ledesma K, Medina C, Maffei L, Amanzo J, Chávez C, Enciso MA, García A, Jeffrey C, Mendoza JA, Rojas G, Silva L, Villegas L, Robert SR, Cruz A (2012) El orden Carnivora (Mammalia) en el Perú: Estado del conocimiento y prioridades de investigación para su conservación. Revista Peruana de Biologia 19: 17-26. https://doi. org/10.15381/rpb.v19i1.783

Di Bitetti MS, De Angelo CD, Di Blanco YE, Paviolo A (2010) Niche partitioning and species coexistence in a Neotropical felid assemblage. Acta Oecologica 36: 403-412. https://doi.org/10.1016/j. actao.2010.04.001

Emmons LH, Feer F (1997) Neotropical rainforest mammals: a field guide. University of Chicago Press, Chicago, 396 pp.

Espinosa CC, Trigo TC, Tirelli FP, Da Silva LG, Eizirik E, Queirolo D, Mazim FD, Peters FB, Favarini MO, De Freitas TRO (2018) Geographic distribution modeling of the margay (Leopardus wiedii) and jaguarundi (Puma yagouaroundi): a comparative assessment. Journal of Mammalogy 99: 252-262. https://doi.org/ 10.1093/jmammal/gyx152

Espinosa CI, Jara-Guerrero A, Cisneros R, Sotomayor J, EscribanoÁvila G (2016) Reserva Ecológica Arenillas; ¿un refugio de diversidad biológica o una isla de extinción? Ecosistemas 25: 5-12. https://doi.org/10.7818/ecos.2016.25-2.02

Giordano AJ (2016) Ecology and status of the Jaguarundi Puma yagouaroundi: a synthesis of existing knowledge. Mammal Review 46: 30-43. https://doi.org/10.1111/mam.12051
Grimwood IR (1969) Notes on the distribution and status of some Peruvian mammals 1968. Special Publication, American Committee for International Wild Life Protection 21. American Committee for International Wild Life Protection / New York Zoological Society, New York, 86 pp.

Hodge AMC, Arbogast BS (2016) Carnivore diversity at a montane rainforest site in Ecuador's Gran Sumaco Biosphere Reserve. Oryx 50: 474-479. https://doi.org/10.1017/S0030605315000101

Hurtado CM, Pacheco V (2015) New mammalian records in the Parque Nacional Cerros de Amotape, northwestern Peru. Revista Peruana de Biología 22: 77-86. https://doi.org/10.15381/rpb.v22 i1.11124

Hurtado CM, Pacheco V, Fajardo Ú, Uturunco A (2016) An updated analysis of the distribution of Cites-listed Peruvian carnivores for conservation priorities. Mastozoología Neotropical 23: 415-429.

Linnell JDC, Strand O (2000) Interference interactions, co-existence and conservation of mammalian carnivores. Diversity and Distributions 6: 169-176. https://doi.org/10.1046/j.1472-4642.2000.0 0069.x

MINAGRI (2014) Decreto Supremo N 004-2014-AG. Ministerio de Agricultura, Lima, Peru.

Nowell K., Jackson P (1996) IUCN, Gland, Switzerland. Wild Cats: Status Survey and Conservation Action Plan 110-113 pp. https:// doi.org/10.1023/A:1008907403806

Oliveira TG De (1998) Herpailurus yagouaroundi. Mammalian Species: 1-6. https://doi.org/10.2307/3504500

Oliveira TG de, Tortato M a, Silveira L, Kasper CB, Mazim FD, Lucherini M, Jácomo AT a, Soares JBG, Marques RV, Sunquist ME (2010) Ocelot ecology and its effect on the small-felid guild in the lowland neotropics. In: Macdonald DW, Loveridge AJ (Eds), Biology and Conservation of Wild Felids. Oxford University Press, 559-580.

Pardo-Vargas LE, Payán-Garrido E (2015) Mamíferos de un agropaisaje de palma de aceite en las sabanas inundables de Orocué, Casanare, Colombia. Biota Colombiana 16: 54-66.

Shannon G, Lewis JS, Gerber BD (2014) Recommended survey designs for occupancy modelling using motion-activated cameras: insights from empirical wildlife data. PeerJ 2: 1-20. https:// doi.org/10.7717/peerj.532

Silva LG, de Oliveira TG, Kasper CB, Cherem JJ, Moraes EA, Paviolo A, Eizirik E (2016) Biogeography of polymorphic phenotypes: mapping and ecological modelling of coat colour variants in an elusive Neotropical cat, the Jaguarundi (Puma yagouaroundi). Journal of Zoology 299: 295-303. https://doi.org/10.1111/jzo. 12358

Tobler MW, Carrillo-Percastegui SE, Leite Pitman R, Mares R, Powell $\mathrm{G}$ (2008) An evaluation of camera traps for inventorying large- and medium-sized terrestrial rainforest mammals. Animal Conservation 11: 169-178. https://doi.org/10.1111/j.1469-1795.2008.00169.x

Zimbres B, Peres CA, Penido G, Machado RB (2018) Thresholds of riparian forest use by terrestrial mammals in a fragmented Amazonian deforestation frontier. Biodiversity and Conservation: 1-22. https://doi.org/10.1007/s10531-018-1571-5 